

\section{ÍNDICE}

\section{ÁMBITOS PERSONALES PERSONAL ÁMBITOS}

Crisis de Venezuela: Análisis y perspectivas según los titulares de la prensa argentina, española y china

Venezuela's crisis: Analysis and perspectives in the headlines of Argentine, Spain and China press

Hui Feng Liu

Tratamiento informativo de la violencia de género: asesinatos de mujeres. Análisis de la agencia EFE

Informative treatment of gender violence: murders of women. Analysis of the press agency EFE Rosa Rodríguez Cárcela, Agustín López Vivas

MONOGRAFICOS MONOGRAPHS

Presentación Monográfico. El universo transmedia de los medios de comunicación universitarios: acción dentro y fuera del aula en la sociedad postdigital

Antonia Isabel Nogales-Bocio, Ángels Álvarez villa

El papel transformador de la radio universitaria en materias teóricas ajenas a la comunicación

The transformative role of college radio in theoretical subjects outside communication

Miguel Ángel Díaz Monsalvo

La radiodifusión universitaria: acción discursiva radiofónica para la divulgación de la ciencia University Radio Broadcasting: Radiophonic Discursive Action for the Science Popularization Jorge Sadi Durón, Joel Zapata Salazar

El uso corporativo de Instagram en las universidades privadas españolas. Estudio comparativo de treinta y cinco universidades

The corporate use of Instagram in spanish private universities. Comparative analysis of thirty-five private universities 
La radio universitaria como herramienta de inclusión social: OndaCampus en contextos como la cárcel y barrios desfavorecidos

The university radio as a tool for social inclusion: OndaCampus in contexts like the prison and disadvantaged neighborhoods

Leonor Real Adame, Daniel Martín-Pena, Macarena Parejo Cuéllar

Hacer radio universitaria en la era de YouTube: uso de la plataforma de vídeos a demanda en el contexto mexicano

Make college radio in the age YouTube: use of video on demand platform in the Mexican context Marina Vázquez Guerrero

\section{ARTÍCULOS ARTICLES}

O impresso e o digital nos modelos de negócios de jornais locais: uma análise do Sermos Galiza

The press and digital in business models from local media: Analysis of newspaper Sermos Galiza

Giovanni Ramos

Publicidad y cáncer en la prensa escrita (1903-1912)

Advertising and cancer in the written press (1903-1912)

Laura Almudéver-Campo, Ramón Camaño-Puig

Game rules vs. fandom. How Nintendo's Animal Crossing fan-made content negotiates the videogame meanings

Las reglas del juego vs. el fandom. Cómo el contenido hecho por fans de Nintendo Animal Crossing negocia los significados del videojuego

Jose A. Moreno

La comedia de situación y su análisis textual: evolución de los elementos constructivos del formato

The sitcom and its textual analysis: evolution of the constructive elements of the format

Darío Martín Sánchez

Análisis del discurso emocional de Donald Trump en la campaña electoral de $\mathbf{2 0 1 6}$ Analysis of Donald Trump's emotional speech on the 2016 election campaign 
Innovar, comunicar y transformar (en) la Universidad

Innovate, communicate and transform (at) the University

María Sofía Bernat

288-292

Transparencia en los medios: Un requisito imprescindible para medir la rentabilidad social en radio y televisión

Transparency in the media: An essential requirement to measuresocial profitability in radio and television

Amanda Salazar

Los estudios feministas en comunicación: representación de las mujeres en la revolución tecnológica

Feminist studies in communication: representation of women in the technological revolution 


\title{
Game rules vs. fandom. How Nintendo's Animal Crossing fan-made content negotiates the videogame meanings
}

\author{
Las reglas del juego vs. el fandom. Cómo el contenido hecho por \\ fans de Nintendo Animal Crossing negocia los significados del \\ videojuego
}

\author{
Jose A. Moreno, Universitat Pompeu Fabra \\ Campus Poblenou. Departamento de Comunicación. Edificio Roc Boronat, c/ \\ Roc Boronat, 138, 08018 Barcelona (España) \\ joseantonio.moreno@upf.edu | Orcid: https://orcid.org/0000-0003-3781-5644
}

DOI: http://dx.doi.org/10.12795/Ambitos.2020.i47.11

\begin{abstract}
This research reviews the ideologies present in the Nintendo's videogame saga Animal Crossing and aims to discover how fans interpret them. The process involves an exploration of the online fanart of the videogame and its classification into reproductive, neutral or critical fandom, depending on the revised operating ideologies. Following, a content analysis and brief semiotic analysis have been conducted to interpret the meanings that fans elaborated and wanted to share with the community. As a result, this research shows that the fandom of Animal Crossing reinterprets the ideologies of the game producing a critique of struggles present in society against sexism and consumerism. However, some fanart is aligned with the neoliberal and sexist ideas that emanate from the canonical text. Thus, analysing fandom's production is a worth way to discover how audiences interact with videogames and how they expand its meanings beyond the game.
\end{abstract}




\section{Resumen}

Esta investigación revisa las ideologías presentes en la saga de videojuegos Animal Crossing de Nintendo y pretende descubrir cómo los fans las interpretan. El proceso consiste en una exploración del fanart del videojuego en internet y su clasificación en fandom reproductor, neutral o crítico, en función de las ideologías del videojuego revisadas. A continuación, un análisis de contenido y breve análisis semiótico ha sido realizado para interpretar los significados que la comunidad fan elabora y busca compartir. Como resultado, esta investigación muestra que el fandom de Animal Crossing reinterpreta las ideologías del juego produciendo una crítica de luchas presente en la sociedad contra el sexismo y el consumismo. En cambio, algunas piezas de fanart están alineadas con ideas neoliberales y sexistas que emanan del texto canónico. En definitiva, analizar la producción fandom es una forma válida para descubrir cómo las audiencias interactúan con los videojuegos y cómo estas expanden sus significados más allá del juego.

Keywords: Animal Crossing, videogames, fandom, ideology, Nintendo, Cultural Studies

Palabras clave: Animal Crossing, videojuegos, fandom, ideología, Nintendo, Estudios Culturales

\section{INTRODUCTION}

Study objects such as fandom and videogames are increasingly analysed by Western academics using the framework of the cultural studies. These cultural objects have powerful meanings that are worth to study for their links with the social struggles of our everyday. At this point, concepts like the governmentality processes in the social life should be considered, given that videogames as cultural products can also perform as governmental practices.

This paper takes as an object of study the fandom community around the Nintendo's videogame saga Animal Crossing. Existing literature indicates that these videogames show consumerist and neoliberal economic ideologies, and notions of gender discrimination.

The methodology of this paper is grounded on cultural studies and take as methods the content analysis and semiotics to examine the meanings of fanart about Animal Crossing. Three categories have been identified: fandom that reproduce the ideologies of the game, ideologically neutral fandom, and fandom that challenge the hierarchies of the game. 


\section{LITERATURE REVIEW}

\subsection{Videogames and govern}

The industry of videogames nowadays is a profitable business that in 2018 reached the amount of 135 billion dollars in revenues (Batchelor, 2018). It is a powerful sector and the idea of videogame as a cultural product is widely accepted. But videogames have promoters and detractors. Often games are criticized for encouraging children isolation or addiction, but others argue that they promote socialization and the learning of teach competences (Levis, 1997).

On the one hand, videogames are a proven and powerful learning tool in different areas such as history and heritage (María \& López, 2006), geography (Clemente, 2014), languages (Del Moral Pérez, Guzmán Duque, \& Fernández García, 2018) climate change (Rojo \& Dudu, 2017), physical education (Gómez-Gonzalvo, Molina, \& Devís-Devís, 2018) or Primary School skills (Del Moral Pérez et al., 2018), among others.

On the other hand, there is a debate about the content of videogames and the effect of violent representations on children. While some scholars point that videogames could be a cathartic way of dealing with violence in social life, others argue that by being exposed to those fictional wars, fights and deaths children, are learning these same behaviours (Levis, 1997). Sexist forms of violence are a relevant issue studied by scholars. A major research that surveyed 13.520 adolescents in France showed that the exposure to videogames is related to sexism (Bègue, Sarda, Gentile, Bry, \& Roché, 2017). One possible answer is the tendency of videogames to reproduce sexist discrimination, sometimes explicitly through the roles assigned to women, and other times implicitly, promoting toxic values from "macho" culture (Díaz Gutiérrez et al., 2004). Conversely, some parts of the videogame such as the covers are not that aligned with classic sexist stereotypes of women, although they are still located in a "macho" paradigm and shows only thin, young, white women (Paredes-Otero, 2018).

Thus, videogames are not an idealized tool for learning, and neither are they machines that pervert children. The issue is that they are cultural products that are consumed and, while doing so, people is also consuming a certain ideology, values and behaviour patterns. Not just violence. We can further understand it by applying the governmentality concept originally coined by Foucault and later developed by sociology scholars.

For Mitchell Dean (2010, p. 19), to govern is "not only how we exercise authority over others, or how we govern abstract entities such as states and populations, but also how we govern ourselves." Hence, government practices in postmodernity encompass the practices of the self. To properly understand it, Dean (2010, p. 20) proposes to analyse the social practices that try to "shape, sculpt, mobilize and work through the choices, 
desires, aspirations, needs, wants and lifestyles of individuals and groups." Since videogames play an important part in the influence of certain groups of people, Dean's theory is highly relevant to devise the ideologies and messages they are transmitting. Therefore, videogame studies should emphasise the analysis of their role regarding government practices.

Liam Mitchell (2018, p. 6) argues that videogames are "digital systems governed by rules." In other words, they are modelled and defined within a sandbox that limits the possibilities the videogame has, no matter how infinite they seem. A similar argument provide Daniel Muriel and Garry Crawford (2018), who explain that videogames are predesigned products according to the hegemonic living patterns, so the freedom of choice is just an illusion. Thus, inside a videogame there is a negotiation between the agency of the player (the ability to act with freedom) and the hegemonic neoliberal logic that emanates from the videogame as a result of the context in which it is made (Muriel \& Crawford, 2018).

Therefore, videogames are just "power fantasies" (Mitchell, 2018, p. 22) that provides the player open worlds, possibility of choice and other mechanisms that "tends toward controllability" instead of promote player's agency. These concepts that shapes the agency of the subject are mostly related with moral behaviours. Ideas such as "freedom, justice, equality, mutual responsibility, citizenship, common sense, economic efficiency, prosperity, growth, fairness, or rationality" (Muriel \& Crawford, 2018, p. 68) are interpreted from a certain point of view, which is neoliberalism.

In that sense, it is worth to highlight that making individuals responsible of their choices is a market tool to disempower citizens. If they feel they are at fault, they will not blame the system. This practice is disseminated through videogames, as it has been reviewed. But we can also understand videogames as all the contrary if developers or players try to break this tangle of structural pressures in which they are in. Specifically, those outcomes are mostly represented in the rise of a participatory culture that goes beyond the meanings provided in the canonical text (Muriel \& Crawford, 2018). Consequently, games studies must take a wider focus embracing fandom studies.

\subsection{Fandom}

The term fan or fanatic is used to describe a person interested in a specific object, concept or person with such enthusiasm that most people could not share the same feeling towards the adorated object or subject. As Jenkins (2012) explains, the term in its origin was related to obsessive religious practices and other negative connotations, and only in the $19^{\text {th }}$ Century the word fan started to be used to refer to the followers of sport teams. In the late $20^{\text {th }}$ Century, fans around phenomena such as Star Trek were conceived as ridiculous people with bad taste (Jenkins, 2012). 
Traditionally, the content produced by fans was considered lower cultural objects in comparison with the canonical text which inspires the fandom para-text (Jenkins, 2012). But, for Jenkins (2012), this is just a division of culture in higher and lower products that follows a classist perspective, according to Bourdieu ideas. This is a way to build discrimination through culture, by linking the other (the lower-class citizen) with a bad taste concept because of a consumption of popular culture.

Nevertheless, for academia, fandom's production and practices are increasingly considered a worthy object of study at the same level of the referred text (Geraghty, 2015). Fandom studies provide knowledge about how audiences interpret and discuss the main text, how they receive meanings and how produce new ones (Geraghty, 2015).

There are three main stages in the study of fandom production since the 80's, according to Jonathan Gray, Cornel Sandvoss and C. Lee Harrington (2017). The first wave of fandom scholars defended fans as a powerful contracultural collective in a context in which they were portrayed by media as weird people. The second wave started to study fandom as a tool to replicate social hierarchies, so fans were not challenging the social hierarchies but also maintaining the cultural systems and social norms. Finally, the third wave of fan scholars shifted the focus onto the empirical content and the subjects to conscientiously/meticulously discover the motivations of fans and the features of their content within the contemporary mediated life.

Nowadays, the fandom is no more portrayed as a marginalized collective but as a desirable social group for brands: the best consumer is the one who spreads the goodness of the product (Linden \& Linden, 2017). In this digital era, influencers are an example of that. By creating their own content they play a key role within the media ecosystem, and being a youtuber becomes the highest expression of the success these prosumers can achieve (Ramos-Serrano \& Herrero-Diz, 2016).

Hence, fans are now considered a profitable value because of their prosumer features, as Mel Stanfill argues (2019). This author applies a Marxist approach to fan practices and the control that brands are performing over then: fans add value to the brands with non-payed labour creating surplus in the media industry (Stanfill, 2019). One related tendency that goes deep in this phenomenon is the fanadvertising. This concept defines the fan-created content which is inspired by a desire to spread their own perspectives about the canonical product (in a positive way) that reaches a high level of virality (RamosSerrano, Lozano-Delmar, \& Hernández-Santaolalla, 2012). By doing that, fan audiences are well received by cultural industries and aimed by them to create content that could be complementary to their marketing strategies (Gray et al., 2017; Ramos-Serrano et al., 2012).

It is worth to apply the aforementioned to the case of Nintendo, that has traditionally leaded the making of a community of players that share more than the act of playing. 
They launched the NES console in the 1980's, which was precisely a starting point of a strategy. The main objective was "to create around the brand and its characters a particular universe capable of attracting both the users of its console and the potential public" (Levis, 1997, p. 73).

They did so the first time during the apogee of NES console, Levis (1997) explains, by subscribing fans to a magazine when they registered their warranty. Over the years, Nintendo tried to make its fans loyal by providing them spaces of community such as clubs, magazines or forums. This strategy continues nowadays with a logic of commodification of nostalgia (Cuff, 2017), that materializes in services like the Virtual Console and shared spaces such as Miiverse. According to Steven Cuff (2017), in Miiverse was common to see fan content like screenshots, stories or anecdotes of fans remembering old times with those videogames. This all to catch the lost fans that first played Nintendo at their childhood, as it has happened with products such as Pokémon: Let's Go, Pikachu! for Nintendo Switch.

Apart from the aforementioned, it is worth to note that a taxonomy that splits fans between "traditional" or "brand" ones could be simplistic (Hills, 2017). As Matt Hills proposes, it is better to conceive fandom as a "set of pathways or branches" or "a network of networks" (Hills, 2017, p. 878) to better recognize the openness and possibilities of fandom universe. To sum up, from the different waves of fandom studies it is possible to extract that fandom content and practices are not contracultural neither replicators of hegemonic meanings. They are both and more if we consider the aim of cultural industries to further develop fandom communities and products.

\subsection{Animal Crossing}

Animal Crossing saga started with the launching of the first game in Japan in 2002 for Nintendo 64 console. The videogame reached the international scene in the next deliver, Animal Crossing. Population: Growing! distributed in the United States, Europe and Australia between 2002 and 2004. But the popularity came with the Animal Crossing: Wild World that reached the $9^{\text {th }}$ position in the most sold videogames of Nintendo DS. Since that deliver, Animal Crossing saga shifted into a more social way of playing, because it took advantage of the Nintendo Wi-Fi Connection to allow visiting other villages and people.

Animal Crossing can be categorized as a simulation videogame because its purpose is to understand how the system (the city, the neighbours) works and, although the system has limits, they permit certain range of experimentation (Pérez Latorre, 2011). In this way, Animal Crossing offers the possibility to interact with neighbours, expand your home, buy objects, and collect insects, fish and fruits to make money. 
This era is marked by the acceleration and the short-termism influenced by the economic system (Concheiro, 2016). In this context, slow games, a specific genre of videogames, are created. Slow games break our accelerated routine, and Animal Crossing is one of them because of the rhythm of the dialogues and interactions in-game (Algaba, 2017). The advantages of Animal Crossing have been discussed in fields such as psychology and education. First, the game could be used as a tool to deal with disorders like depression or anxiety, in part due to the slow mechanics refereed previously (Garcia, 2017). Second, scholars have tested the features of Animal Crossing and recommended the title for its learning potential related to creativity, strategic thinking, cognitive development and social skills (Ramalho, Simão, \& Paulo, 2014).

One key feature of Animal Crossing is that it was designed to be shared and avoid isolation. Apart from the online features, you can share the game with your social environment by creating various characters in the village. This functionality was designed to provide a multiplayer experience to those players who play at different hours, specially within the family (Algaba, 2017).

But Animal Crossing have also other side that must be inspected. The game is built on a fierce consumerist logic (Algaba, 2017; Bogost, 2008; Kim, 2014). As Bogost (2008, p. 119 ) depicts, Animal Crossing is not only about collecting objects and talking with neighbours, but also "about the repetition of mundane work necessary to support contemporary material property ideals". The beginning differs between the different titles of the saga, but the common start for the player is coming to a village with no money at all. The racoon Tom Nook, the businessman of the village, either offers the player a job or he explains how to get started. Basically, the logic inside the game is a vicious circle: to buy and fit furniture into your house, you need to expand it. By expanding it, there will be more space for more furniture and Toom Nook will provide more items, which you will want to buy because they are new. Buying more furniture will progressively require extra expansions, Then the same process is repeated. In the meantime, you can see how Tom Nook increases his wealth and reforms his shop to provide more goods with each expansion of your house.

Jin Kim (2014) recognizes that videogames teach lessons and provide knowledge and fun, but also stresses that this process is ideologically biased. The functioning of Animal Crossing to pay the loan pull the player to do repetitive tasks in a sense that reminds Taylorism. This process makes players comfortable with the idea of investing time in the game because they have the illusion of work, the preferable way of using time in a neoliberal society (Kim, 2014). Thus for Kim (2014), players of Animal Crossing are receiving economic ideology through the game and they are also actively accepting it.

For its part, Pablo Algaba (2017) compares the logic of Animal Crossing with the entrepreneurial culture. The player does not have a job but must collect fruit, fossils, shells or 
other objects to sell it to Tom Nook to make money, i.e. she is a self-employed worker. As an experiment, Algaba tried to play expending no bells and just doing barter and interacting with neighbours without visiting the shop. The result was that many parts of the game were not enjoyed and was "impossible to completely challenge the norms that govern the game economy” (Algaba, 2017, p. 67).

Conversely, there is also a gender issue in Animal Crossing, although authors like Algaba (2017) indicate that the last game of the saga, Animal Crossing: New Leaf, shows certain progress in gender diversity. While in the early titles of the saga the clothes were automatically shaped in shirt/skirt depending on the chosen sex of the player, in New Leaf you can wear a skirt being boy or a shirt being girl. Nevertheless, Algaba criticizes a specific issue within the game regarding gender roles: when the player shows crossgender attitudes, other characters comment and criticize the decision with unappropriated comments.

In the same way the artist lo Kain (2015) challenges the gender discrimination that the game performs. Neighbours and shop assistants only comment the look of the player if it does not fit with the chosen sex. The artist stresses the irony of the game, presented in marketing campaigns as a totally customizable game. Thus, far from reality, Animal Crossing is not that free and entirely yours game that you can govern as you want. The game is already governed by the same neoliberal and sexist rules that shape our everyday life.

\section{METHODOLOGY}

\subsection{Research question}

This research is guided by the following research question: How does Animal Crossing Fandom reproduce, ignore or challenge the hierarchies and ideologies present in the videogames of the saga that have been identified in previous literature?

\subsection{Rationale}

The relevance of study Animal Crossing's fandom lies in that this game has a very active community on the internet. Since it is a popular game and promotes the socialization between players online, it is interesting to study such communities and their fan content. There are several studies about the ideologies behind Animal Crossing or its educational potential, but there is no analysis of its fandom.

\subsection{Perspective and theoretical framework}

This research is grounded in the critical theory paradigm, which asserts that social practices are influenced by a social structure that determine them (Brown, McLean, \& 
McMillan, 2018). Within the communication field, the critical media studies see communication practices as biased actions that shape our understanding, thus they should be studied as vehicles for ideology and values (Lindlof \& Tylor, 2017).

This research follows the specific current of the critical studies denominated cultural studies. The aim of the cultural studies is to focus on the culture as a tool for the dominant structures which shapes our everyday (Lindlof \& Tylor, 2017). Concretely, cultural studies have an anti-elitist perspective that is concerned about the cultural manifestations traditionally considered inferior or consumed by working-class groups (Lindlof \& Tylor, 2017). In the encounter with media studies, cultural studies stresses that communicational products have political meanings that people interact with (Lindlof \& Tylor, 2017).

The objects of this research, videogames and fandom, are issues which concern the cultural studies field because they are popularly considered lower cultural practices in comparison with literature, cinema or other 'high culture' manifestations. Additionally, for the purpose of this research, fandom is understood as "a collective strategy, a communal effort to form interpretive communities that in their subcultural cohesion evaded the preferred and intended meanings" (Gray et al., 2017, p. 2). Based on this concept, we can further understand the role of fandom in the interpretation of hegemonic meanings placed in videogames.

\subsection{Methods and tools}

This research performs a qualitative content analysis of the Animal Crossing's fandom production. The unit of analysis is the fanart content such as drawings, caricatures, memes and YouTube videos. To gather the sample an exploratory process through internet search engines has been followed. This process then continued within the search engines of particular platforms where fandom produce content, such as Devianart, Twitter, YouTube and others. Sampling has been done by introducing the keywords "Animal Crossing" alone or with "fandom", "art", "draw" and "meme".

The results have been explored to pick cases that could fit in in the categories defined by the research question. There are three analytical categories: fanart that reproduce ideologies of the game, fanart neutral regarding those ideologies and fanart that challenges them. For the scoop of this work, only have been collected 18 pieces, attempting to gather representative arts of each category analysed.

The process of analysis involves different methods and tools. First, a qualitative content analysis has been conducted in order to identify the ideologies presented in the fanart. Content analysis is the technique that permits the analyst to look in media content some features or categories previously defined (Hansen \& Machin, 2013). In this case, these features are the meanings for, neutral and against the ideologies present in Animal Crossing videogames (consumerism-neoliberalism and sexism-heteropatriarchy) and 
signs of fan exploitation to the benefit of the brand. To continue, semiotics has been useful to complete the discursive analysis to understand how meanings are generated through signs (Hansen, Cottle, Newbold, \& Negrine, 1998). The purpose with this methodology is to better link the written texts with symbols, meanings and signs presented in the visual text.

\section{RESULTS}

\subsection{Fandom that reproduce}

This section identifies pieces of fandom that reproduce the neoliberal and sexist ideologies presented in the game and identified in the literature review. Regarding gender, it was found a wide spectrum of sexism that vary from incitation to sexual harassment to heteronormative representations of romantic love.

Usually, the sexist representations of Animal Crossing are referred to Isabelle (figure 1), the secretary of the mayor. She is kind, efficient and considerate, and her good manners converted her in one of the most popular icons of the saga since the launch of Animal Crossing: New Leaf. With her popularity plenty of fans took her as 'waifu', a term used in fandom communities to design your favourite character of a manga or other content that you consider your wife. The masculine homologue is the 'husbando'. These fictional relationships promote fanciful fanart that in several cases is erotic or even pornographic.

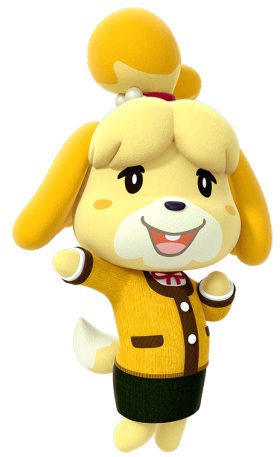

Figure 1. Animal Crossing's character Isabelle Source: ( 2019 Nintendo.

In the video "Animal Crossing - Isabelle Fan Art" (figure 2), a making of a piece of art, there is an example of a sexist representation of Isabelle. The image could be considered furry because it humanizes the character to an extreme (Animal Crossing characters are anthropomorphic, but this art is one step further). The erotization of Isabelle in her job is a common topic in this fandom community. It is interesting how the community interact trough the comments. One user says: "I still cannot understand why people need to sexualize everything that moves." And other answers: "It's human nature. We've done it since the stone age." This conversation is interesting since they show current fights in 
the contemporary society regarding gender discrimination: while one stresses the discrimination, others justifies the hegemony of the heteropatriarchy.

More impressive is the fanart "Isabelle Alt" (figure 3) that represents a situation of rape or BDSM. The tied Isabelle with her attributes exaggerated reify her body and present her as an object. In this case other fans have been more forceful rejecting the image.

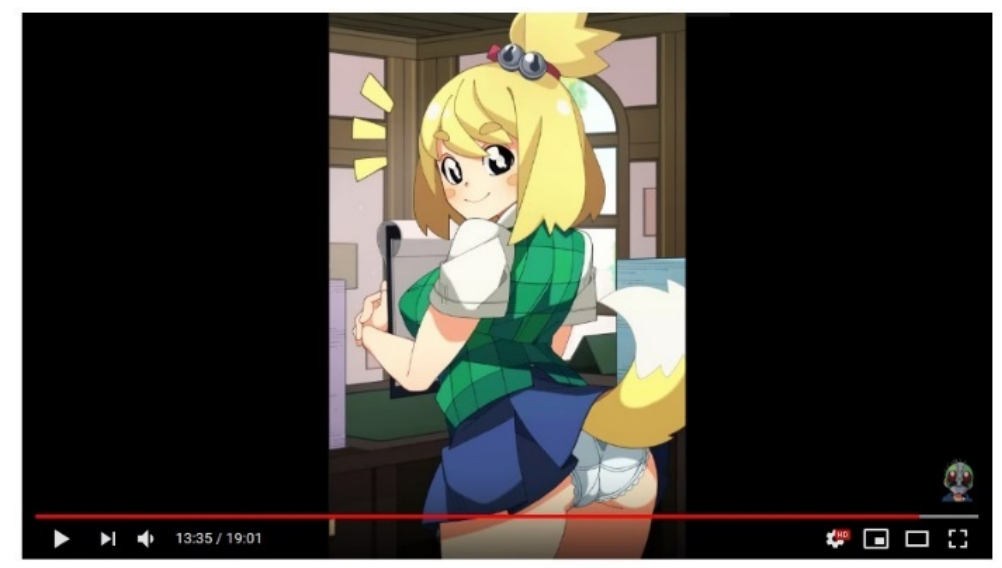

Animal Crossing - Isabelle Fan Art

Figure 2. "Animal Crossing - Isabelle Fan Art"

Source: YouTube (author: Nisego Channel).

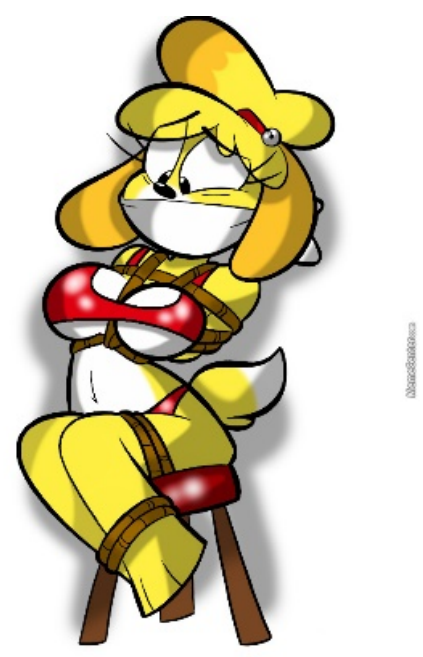

Figure 3. "Isabelle Alt"

Source: Memecenter (author: Teamlpsandacnl).

The art piece "Super Smash Brothers Ultimate - Isabelle and Villager reunited" (figure 4) presents the ways in which fans interpret the arrival of Isabelle as a fighting character in another Nintendo game, Super Smash Bros for Switch in 2018. This piece explores one 
situation that happens in the canonical text Animal Crossing: New Leaf. In San Valentine's Day, Isabelle turns emotional and pretends to show love toward the mayor, independently of the gender. Fans created plenty of 'slash' and 'shipping' content from heteronormativity to queerness. This drawing is one of them that could be placed within the heteronormal representation of a character whose sexual orientation is not clearly defined.

For its part, in "Animal Crossing: Gender Glitch" (figure 5) it is recognizable a situation that happened to a player of New Leaf. The user received a dress from a neighbour, and he found it extraordinary because his character is male. Thus, the user uploaded it to YouTube and tagged it as a glitch, considering that receiving a dress if you are a boy is nothing but a computer error.

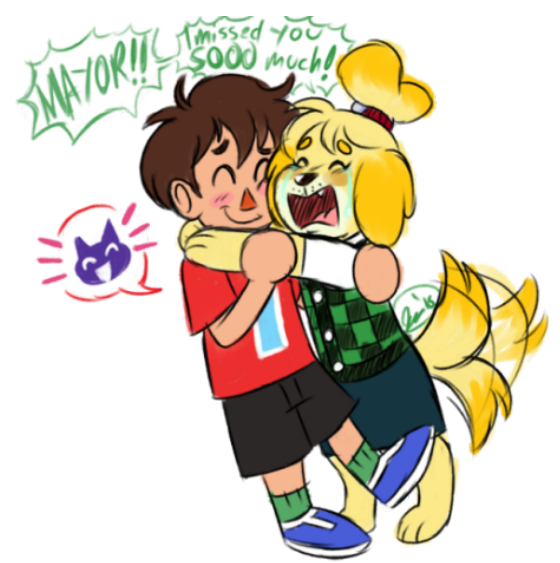

Figure 4. "Super Smash Brothers Ultimate - Isabelle and Villager reunited" Source: KnowYourMeme (author: Starchie).

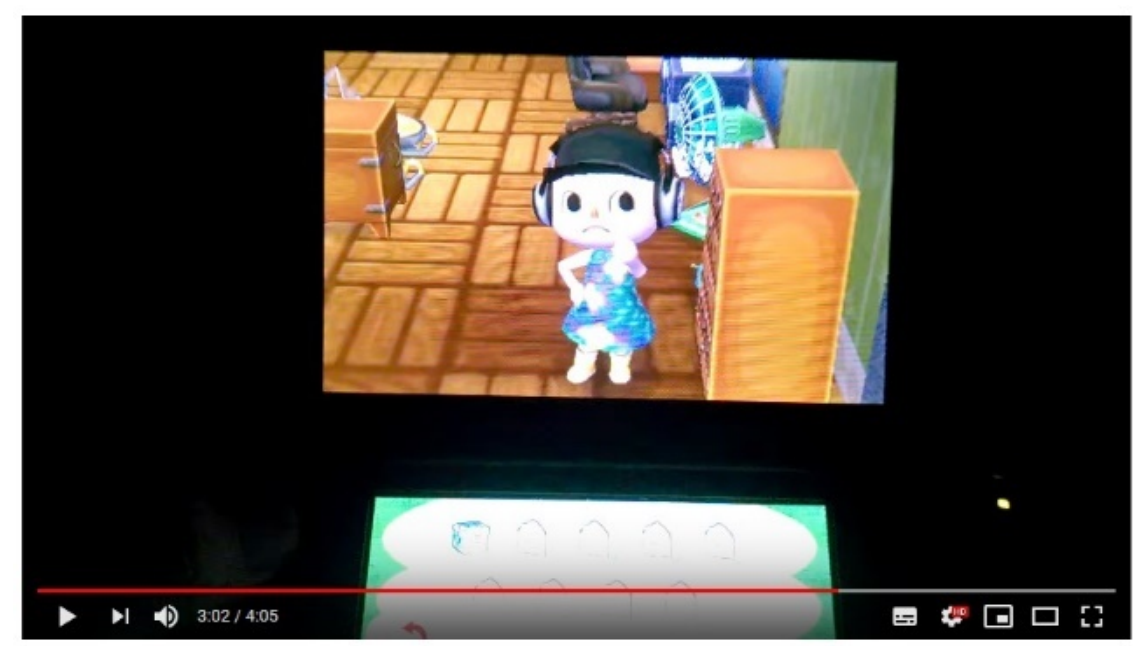

Animal Crossing: Gender Glitch

Figure 5. "Animal Crossing: Gender Glitch"

Source: YouTube (author: $16 \mathrm{mmDJ}$ ). 
Regarding the neoliberal and consumerist component of Animal Crossing, there are two fan videos that exemplify the reproduction of the economic ideology beyond the game. In the "Amiibo review" (figure 6), a fan comments some accessories of the game, an action which encourages others to collect them. "Animal Crossing Trailer (fan made)" (figure 7), is a fictional promotional video which was created using the 'hype' for the launch of Animal Crossing for Switch. These manifestations can be considered as fanadvertising, as far as they are non-official collaborations that promotes the brand.

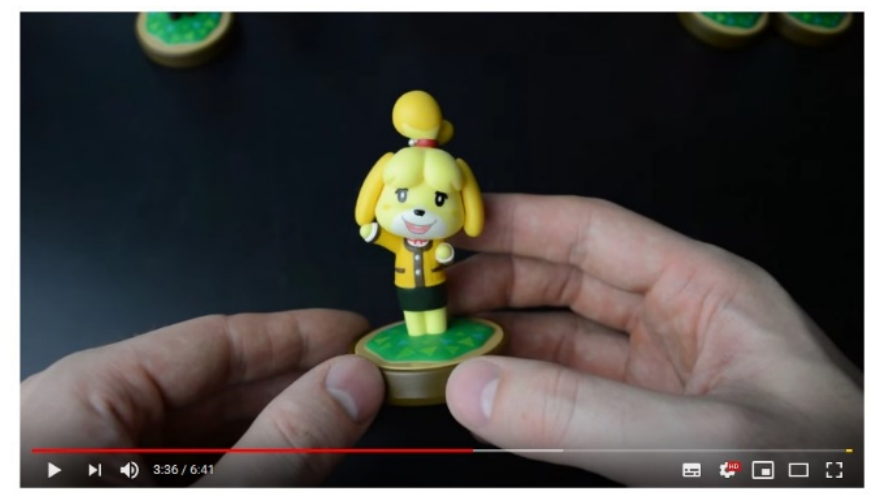

Amiibo review: Animal Crossing, Wave 1 7.931 visualizaciones

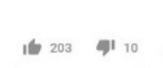

Figure 6. "Amiibo review: Animal Crossing, Wave 1" Source: YouTube (author: Finngamer).

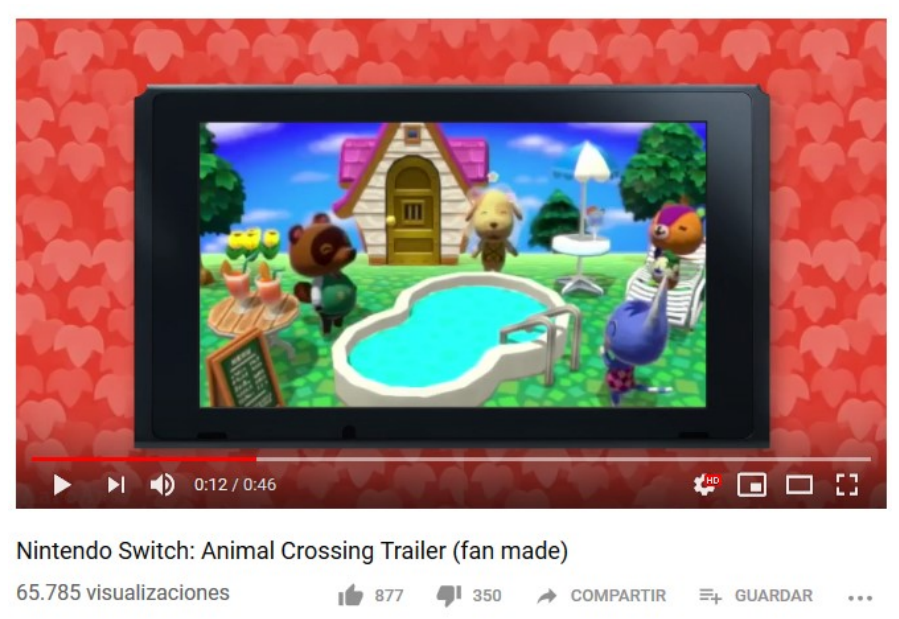

Figure 7. "Nintendo Switch: Animal Crossing Trailer (fan made)" Source: YouTube (author: Mayor Mori).

It is worth to comment the 'commissions' procedure that some fans carry on (figure 8). They offer drawings in Animal Crossing style that can be payed in Animal Crossing bells. This is interesting because it is a way of expanding the economic relations of the game beyond the canonical text. As it was reviewed before, the entrepreneurial component is in the Animal Crossing functioning, but fans can interact with it by reproducing it. 

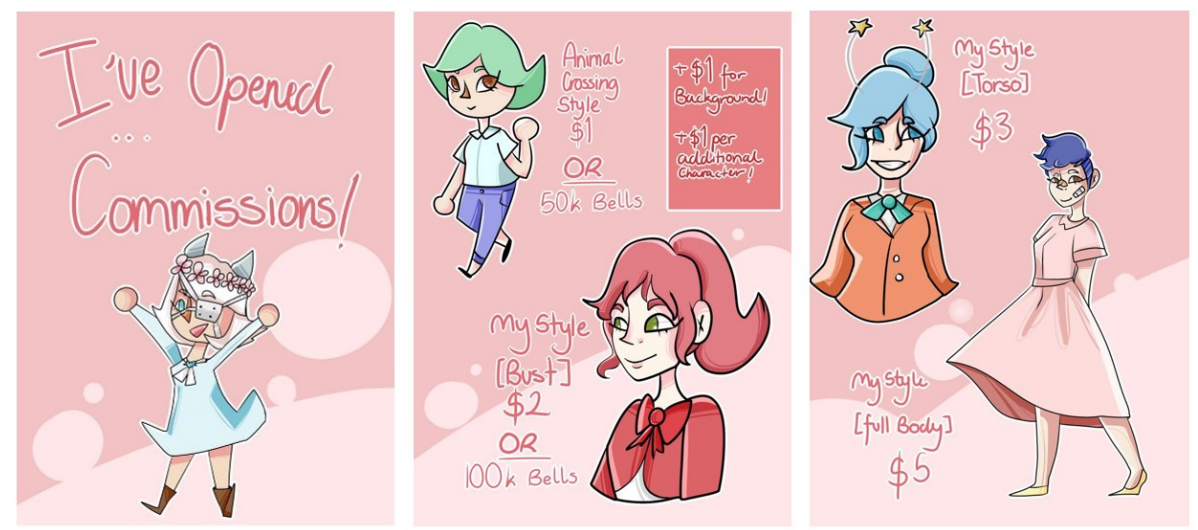

Figure 8. "Comissions! [Re Post]"

Source: AminoApps (author: BanetteDoddles).

Finally, fanart of Animal Crossing is not limited to drawings. The community also develops more elaborated pieces, like the video "Isabelle Ruins Everything (Animal Crossing Parody)" (figure 9). It is difficult to locate this piece in this category or in the challenge one. On the one hand, the video is a parody of Marxism and narrates what happened in the Animal Crossing village with the mayor left for one year and with a communist Isabelle in charge. But, on the other hand, it can be interpreted as a parody of the consumerism that governs Animal Crossing, when the mayor asks people to stop revolution because they do not need the "proletariat liberty" they are asking for. In this case, the mayor could be understood as the capitalist agent that comes to rescue the society from Marxism. The controversy is solved with the release of a butterfly as distractor element and the neighbours running to catch them. So, it could be interpreted from a critical Frankfurt School perspective as the role of the entertainment and cultural industries to maintain the status quo. Because of that it is ambiguous to classify.

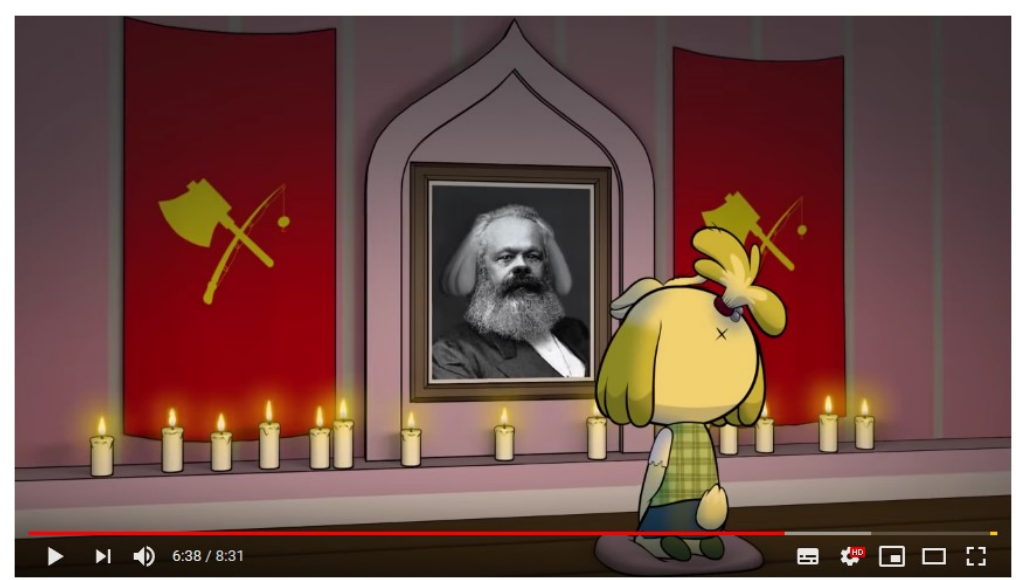

Isabelle Ruins Everything (Animal Crossing Parody)

Figure 9. "Isabelle Ruins Everything (Animal Crossing Parody)" Source: YouTube (author: Hotdiggedydemon). 


\subsection{Neutral fandom}

Perhaps the less interesting fanart regarding the purpose of this research is the neutral one. Although there are pieces that reproduce the hegemonies presented in the game, there are plenty of them that do not interact with those power relations. Instead, these pieces just want to make humour regarding absurd situations of the game or making 'memes' re-signifying the content of Animal Crossing, as occurs in figure 10.
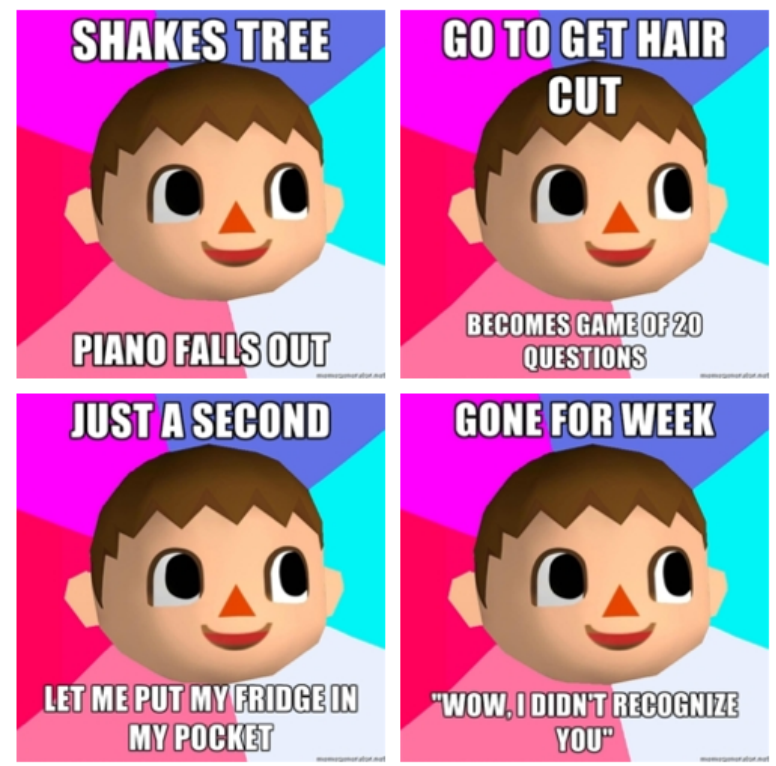

Figure 10. "Acnl Villager Memes"

Source: Meme Pics 2019 (author: Heather).

Usually, those memes and funny art pieces are created with online tools and distributed through social media like Pinterest, Tumblr, Twitter or Facebook. They tend to reach virality. So, plenty of images that are practically the same circulate on the internet without a clear authorship.

\subsection{Fandom that challenge}

Not all fandom reproduces or keep neutral with the ideologies presented in Animal Crossing. First, looking over the sexist issue, there are fanarts that challenge the abovementioned. First, in the cartoon "Why do people keep drawing me naked" (figure 11) a fan criticizes the proliferation of porn and sexist content about Isabelle. Second, in the video "Animal Crossing New Leaf, cross dressing makes you run like a girl" (figure 12) a fan discovers that the developers designed the way of running depending of the clothing. Although the video does not represent an explicit critic, the act of recording and uploading it as an extraordinary event is a critique itself. This process is the same as the "gender glitch" presented before, but in the opposite sense. 


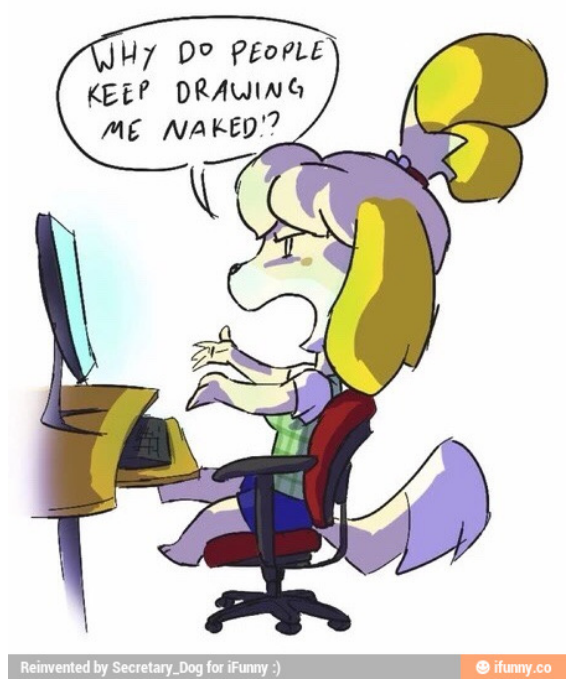

Figure 11. "Why people keep drawing me naked?"

Source: KnowYourMeme (author: Kazenoabs0).

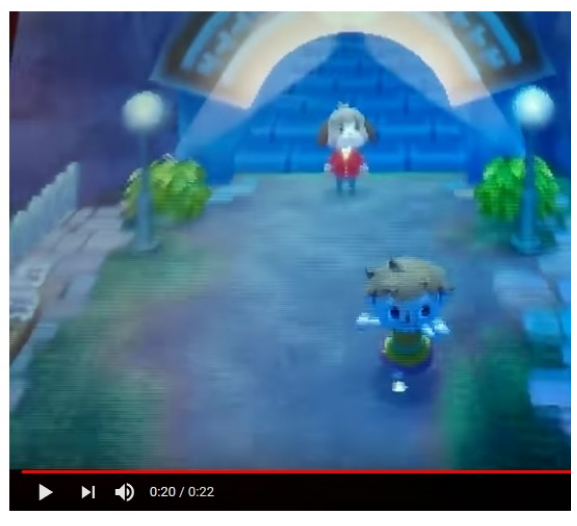

Animal crossing new leaf, cross dressing makes you run like a girl.

Figure 12. "Animal crossing new leaf, cross dressing makes you run like a girl” Source: YouTube (author: Aliensliveinme).

There are more fanart pro LGBTQ+ approaches. In a Twitter account called 'Isabelle facts', the first 'fact' exposed is that Isabelle is a LGBTQ+ character (figure 13). This is an interpretation of the situation on Valentine's Day aforementioned, but behind a queer focus. In this case, fans put the pansexual flag behind Isabelle, and tag her with the pansexual orientation, challenging other versions that tends to be heteronormal. For its part, in the tutorial "Animal Crossing New Leaf: Crossgender Haircuts" (figure 14) a player shows the way to have a hairstyle that does not fit with the assigned gender and celebrates it. 


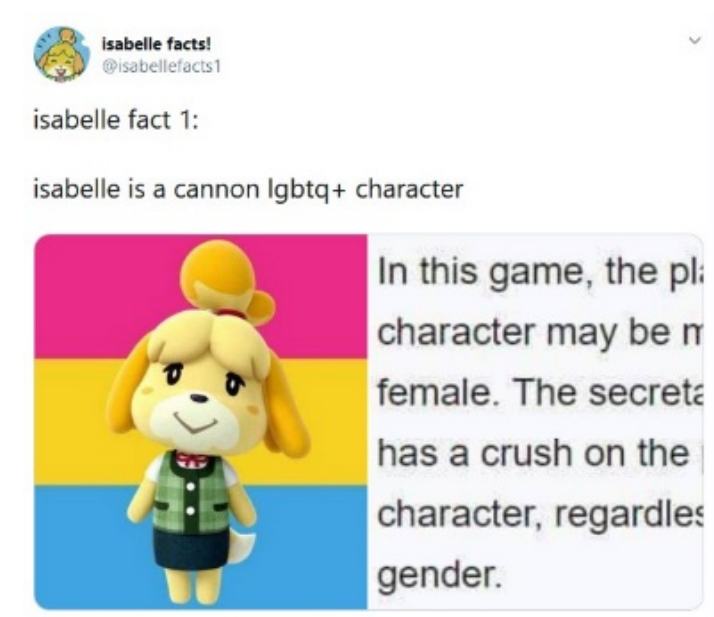

Figure 13. "Isabelle fact 1 "

Source: Twitter (author: Isabellefacts1).

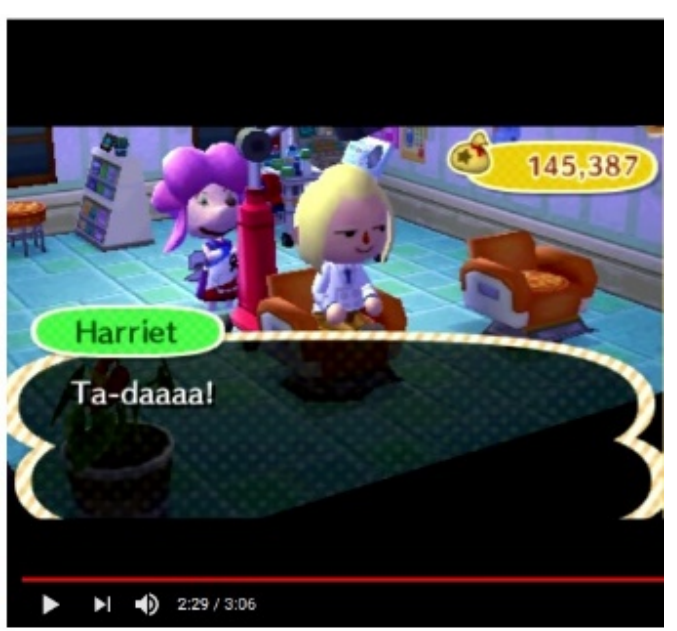

Animal Crossing New Leaf:Crossgender Haircuts

Figure 14. "Animal Crossing New Leaf: Crossgender Haircuts"

Source: YouTube (author: Cosmic kevvv).

The piece "Oh, Mayor!" (figure 15) also follows this current, doing a femslash between the secretary and the female mayor that is the character of the drawer self-represented. These fantasies are common in the fandom, but they tend to be more romanticized than erotic or pornographic as it occurs behind the heteronormative perspective. Also, it exists intertextual femslash in the Animal Crossing saga. Lottie, a character introduced in the Happy Home Designer deliver, is often shipped in a relationship with Isabelle (figure 16). 


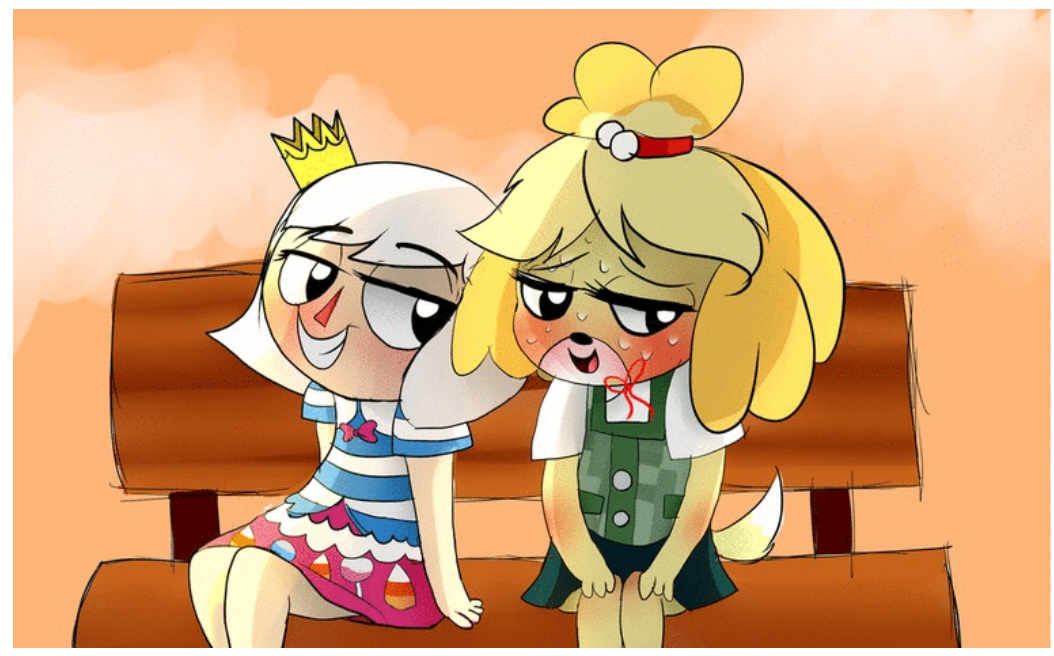

Figure 15. "Oh, mayor!"

Source: Devianart (author: MissPolycysticOvary).

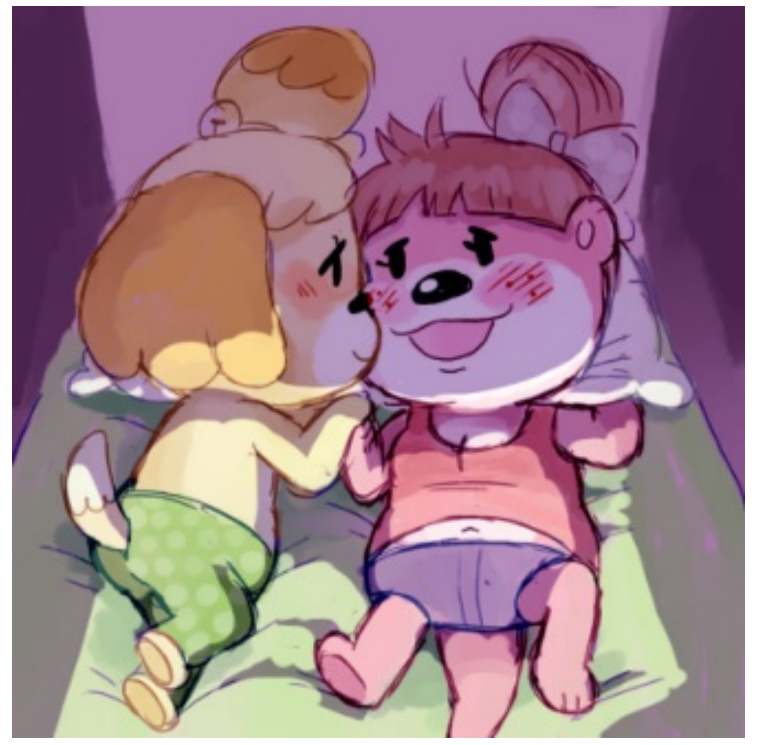

Figure 16. Isabelle and Lottie drawn by 'Computer Garden' independent artist Source: Tumblr (author: Computer Garden)

The following piece is from Leven, a player with $85 \mathrm{~K}$ subscribers in YouTube that has a series of Animal Crossing gameplays. In this case (figure 17) she is showing the game to another youtuber, SaG. While SaG is creating his character, he is impressed by the questions of Fran, the cat that welcomes players to the village of Animal Crossing. Basically, the gender selection depends on a question about how good your name is: if you answer that is cool, the game assigns you a male gender, and if you say it is cute, it supposes that you are a girl. The youtubers criticize it and Leven explain that this question reflects the deep patriarchy in Japanese society. 
On another note, the title of this gameplay "Damned neoliberal mayor!" is a joke that SaG make when Leven says that she chose the wealthy ordinance for her village. This rule permits you to earn more money but also having higher prices in the shops. This commentary can be interpreted as an identification of the ideologies that are in the game.

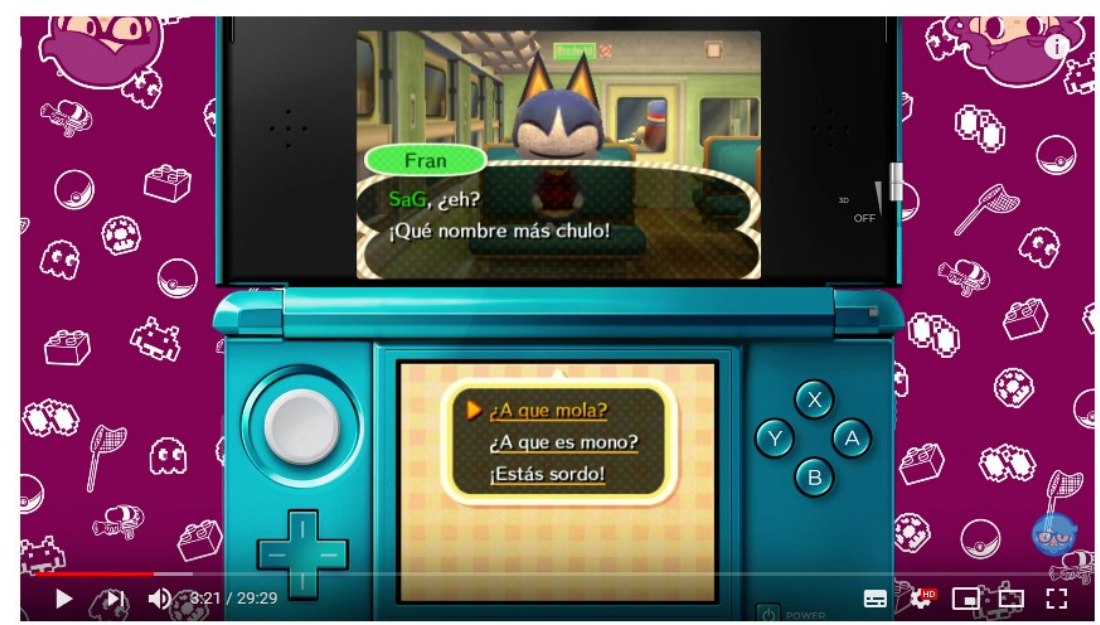

¡MALDITA ALCALDESA NEOLIBERAL!: Animal Crossing New Leaf para 3DS \#JugamosaDobles \#LaVenganzaDeLeven

Figure 17. "¡MALDITA ALCALDESA NEOLIBERAL!: Animal Crossing New Leaf para 3DS \#JugamosaDobles"

Source: YouTube (author: Los Juegos de SaG).

Furthermore, the economics of Animal Crossing are present in the critiques of fans. The "Where's my Money?" (figure 18) art shows a link between the discourse of Tom Nook, the tycoon of the village, with a personal interpretation of the fan. This artwork expresses the helplessness of the situation, since you are always under a loan to pay to Tom Nook. The typography used is the same as the saga, which invites the reader to imagine the title of Animal Crossing to be "Where's my Money?" instead, reflecting one of the principal game mechanics.

On the other side, the cartoon of the female protagonist of Animal Crossing with a pamphlet (figure 19) is really interesting for this analysis. It provides a connection between the Occupy Wall Street movement against the corporativist practices and Animal Crossing. In this case, the slogan is "\#OccupyTomNook", making a parallelism between Wall Street and Tom Nook's shop. 


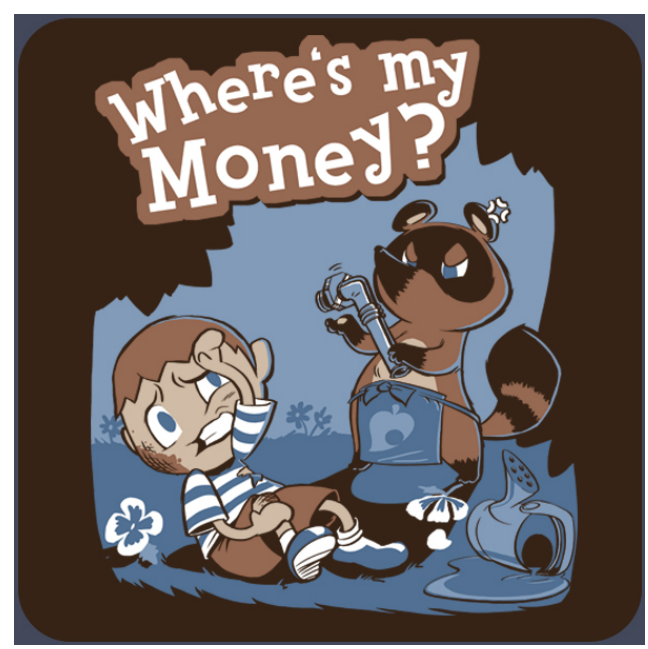

Figure 18. Tom Nook and the villager drawn by a fan Source: KnowYourMeme (author: RandomMan).

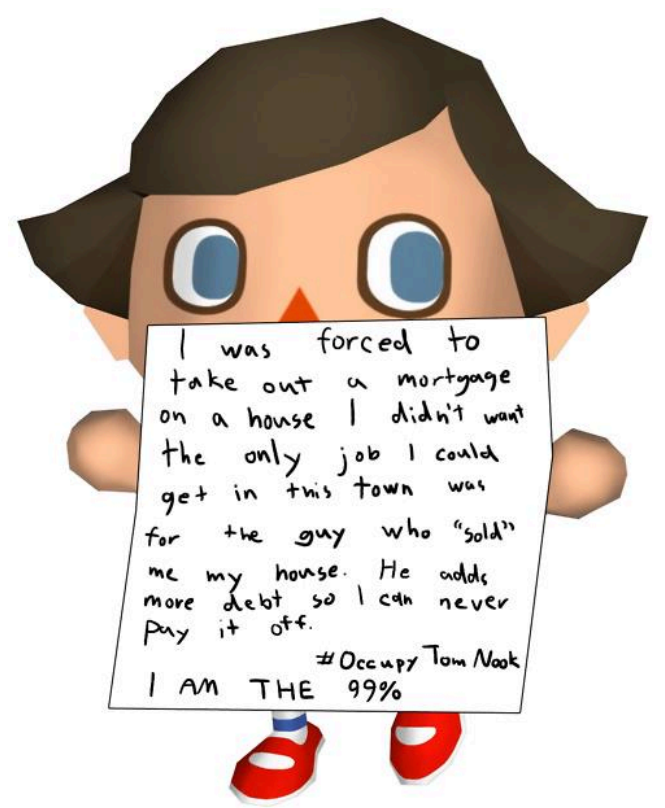

Figure 19. "Occupy Animal Crossing"

Source: STFU Conservatives (blog). Author: Joetheblogger.

\section{DISCUSSION}

The research outcomes are aligned with the idea of Gray, Sandvoss and Harrington (2017) that fandom communities are a way in which people perform in a mediated era. In this case, this research shows how fans create content that interacts with the canonical text. But this fandom is not just a contracultural communication channel nor a simple way of reproducing the pre-existed hierarchies, they are part of a diverse world (Hills, 2017). 
At this point, each one of the fandom studies waves (Gray et al., 2017) help to interpret these outputs. From the first wave it could be taken the notion of value toward fandom communities. Fandom is just another way of participating in the public sphere, but around a desired object. From the second wave, the notion of hierarchies is useful to notice that fans can reproduce ideologies in their content or all the contrary. And from the third wave, it is interesting to discover at micro level how the art pieces interact with meanings from real live, linking struggles or just showing the interesting parts that make fans love the canonical text.

Furthermore, the fanadvertising concept (Ramos-Serrano et al., 2012) and the exploitation of fans by brands (Stanfill, 2019) deserve an extra mention, as it is clearly present in some of the analysed pieces. As scholars such as Levis (1997) and Cuff (2017) have mentioned, this is part of a marketing strategy that companies like Nintendo perform since their foundation.

Finally, regarding sexism, it is worth to point out that community struggles could force changes in the canonical text. Various authors commented that there is a tendency towards the diversity (Algaba, 2017; lo-Kain, 2015) but there is still a lot of pending work. If the community show their requests, next delivers could take it into account to fulfil the desires of fans. After all, they are the clients.

\section{CONCLUSION}

This research shows how the fandom community of Animal Crossing interacts with the canonical text by producing fan content online. This content is worth to study because it carries certain implications and ideologies very related with the canonical text. In this case, and regarding the research question, the research output could be summarized in the following ideas.

The fandom that reproduces the hierarchies presented in the game follows two currents: First, although the game has some sexist components, the content drawn by fans reflects visions that come from the outside, from the performance of gender in real social life. The hegemonic heteronormativity in our society entails not only a sexual orientation (Jackson, 2006), but also a way of life. This way of life derives in discriminatory situations related to rape culture or to the objectification of women. In the fandom analysed, it was demonstrated how fans usually utilize the figure of Isabelle interpreting an abstract event in the game from a heteronormal perspective. This is problematic when fanarts carry this event to an extreme, i.e. fantasizing with sexual harassment and pornography.

It is also interesting to apply a critical perspective to examine the underlying economic ideology of the game and how fans could reproduce it. Practices such as using the game's currency in real life extend the entrepreneurial logic that promotes the videogame. Also, apparently inoffensive content such as gameplays and reviews should be 
critically consumed to face these values that videogames have. Shifting the focus toward the marketing strategies that promote those practices is a greater approach. Fans are not only creating this content for fun but aimed by the creators of the canonical text.

Thereon, the fanart classified as neutral content does not provide ideologically problematic material for analysis and criticism. Gags, funny quotes and memes are the most viral content within the fan community, but they usually do not carry any significant message from an ideological perspective.

Finally, the most interesting part is how fans create content to expand the limits of the videogame. They reimagine particular situations in the game through their art, emphasizing the importance of diversity. Regarding gender, plenty of LGTBQ+ players and other fandom members create art pieces that challenge the rigid and discriminatory categories of the game. Their art often criticizes other fans that reproduce the hierarchies of the game or make them worse.

In the economic ideological field, critical fans elaborate ingenious work that challenges the consumerism and neoliberalism present in Animal Crossing. They do so with humour, but not the innocuous one that some memes have. They connect real struggles such as the protest movement Occupy Wall Street or the pressure of the financial system over people, and they implement them in their artwork. Although this is a minority of the fandom content, is worth to comment this stronghold for its value and interpretation of the videogame ideas.

To finish, this research places value on the microanalysis of fandom pieces, given that we can extract knowledge of how fans receive the videogame ideologies by analysing this content. Also, an interesting question that this research opens and that could be exploited by future works is the interaction between fans in the fanart comment boxes and forums. Usually they left opinions, criticized or praised their work, so this is a good way to know the acceptance of these values within the community. To sum up, fandom is a universe that is worth to explore. The slogan 'Customize your world' that Nintendo gave to the Animal Crossing: New Leaf is nothing but an old-fashioned ideal. Now the fandom customizes their world beyond the game, on the internet.

\section{References}

Algaba, P. (2017). La aldea feliz. Un viaje a través de Animal Crossing. Bollullos de la Mitación (Sevilla): Héroes de Papel.

Batchelor, J. (2018). Global games market value rising to $\$ 134.9 \mathrm{bn}$ in 2018. Retrieved March 28 , 2019, from GamesIndustry.biz website: https://www.gamesindustry.biz/articles/2018-1218-global-games-market-value-rose-to-usd134-9bn-in-2018 
Bègue, L., Sarda, E., Gentile, D. A., Bry, C., \& Roché, S. (2017). Video Games Exposure and Sexism in a Representative Sample of Adolescents. Frontiers in Psychology, 8. https://doi.org/10.3389/fpsyg.2017.00466

Bogost, I. (2008). The rhetoric of video games. In K. Salen (Ed.), The ecology of games: Connecting youth, games, and learning (pp. 117-140). Cambridge: The MIT Press.

Brown, G., McLean, I., \& McMillan, A. (2018). The Concise Oxford Dictionary of Politics (4th ed.). https://doi.org/10.1093/acref/9780199207800.001.0001

Clemente, J. J. (2014). El videojuego SimCity como recurso para la enseñanza-aprendizaje de la Geografía en Bachillerato. In M. C. Domínguez \& M. . Cacheiro (Eds.), Diálogo entre culturas: Estrategias didácticas y tecnologías educativas. IV Congreso Pizarra digital. Madrid: UNED.

Concheiro, L. (2016). Contra el tiempo: filosofía práctica del instante. Barcelona: Anagrama.

Cuff, S. (2017). Now You're Playing with Power: Nintendo and the Commodification of Nostalgia (University of Wisconsin Milwaukee). Retrieved from https://dc.uwm.edu/etd/1459

Dean, M. (2010). Governmentality: Power and rule in modern society (2nd ed.). London: SAGE Publications.

Del Moral Pérez, M. E., Guzmán Duque, A. P., \& Fernández García, L. C. (2018). Game-Based Learning: Increasing the Logical-Mathematical, Naturalistic, and Linguistic Learning Levels of Primary School Students. Journal of New Approaches in Educational Research, 23(76), 31-39. https://doi.org/10.7821/naer.2018.1.248

Díaz Gutiérrez, E. J., Terrón Bañuelos, E., García Gordón, M., Rojo Fernández, J., Cano González, R., Blanco Jorrín, B., \& Castro Fonseca, R. (2004). La diferencia sexual en el análisis de los videojuegos. Madrid.

Garcia, C. (2017). Game Therapy: Animal Crossing \& Anxiety. Retrieved April 4, 2019, from Screen Therapy website: https://screentherapyblog.wordpress.com/2017/10/04/gametherapy-animal-crossing-anxiety/

Geraghty, L. (2015). Popular media cultures: Fans, audiences and paratexts. Hampshire: Springer.

Gómez-Gonzalvo, F., Molina, P., \& Devís-Devís, J. (2018). Los videojuegos como materiales curriculares: una aproximación a su uso en Educación Física. Retos, 34, 305-310. Retrieved from https://recyt.fecyt.es/index.php/retos/article/view/63440/39542

Gray, J., Sandvoss, C., \& Harrington, C. L. (2017). Fandom: Identities and communities in a mediated world. New York: NYU Press.

Hansen, A., Cottle, S., Newbold, C., \& Negrine, R. (1998). Mass communication research methods. New York: NYU Press. 
Hansen, A., \& Machin, D. (2013). Media and communication research methods. Basingstoke: Palgrave Macmillan.

Hills, M. (2017). From fan culture/community to the fan world: Possible pathways and ways of having done fandom. Palabra Clave, 20(4), 856-883. https://doi.org/10.5294/pacla.2017.20.4.2

lo-Kain, N. (2015). Girl glasses: Avatars in Animal Crossing. Retrieved April 5, 2019, from Silverstring Media website: http://meminsf.silverstringmedia.com/identity/girl-glassesavatars-in-animal-crossing/

Jackson, S. (2006). Interchanges: Gender, sexuality and heterosexuality: The complexity (and limits) of heteronormativity. Feminist Theory, 7(1), 105-121. https://doi.org/10.1177/1464700106061462

Jenkins, H. (2012). Textual poachers: Television fans and participatory culture (2nd ed.). New York: Routledge.

Kim, J. (2014). Interactivity, user-generated content and video game: an ethnographic study of Animal Crossing: Wild World. Continuum, 28(3), 357-370. https://doi.org/10.1080/10304312.2014.893984

Levis, D. (1997). Los videojuegos, un fenómeno de masas: qué impacto produce sobre la infancia y la juventud la industria más próspera del sistema audiovisual (1st ed.). Barcelona: Paidós.

Linden, H., \& Linden, S. (2017). Fans and Fan Cultures. In Fans and Fan Cultures: Tourism, Consumerism and Social Media. London: Palgrave Macmillan UK.

Lindlof, T. R., \& Tylor, B. C. (2017). Qualitative Communication Research Methods (4th ed.). Los Angeles: SAGE.

María, J., \& López, C. (2006). La enseñanza de contenidos sociohistóricos y patrimoniales a través de los juegos informáticos de simulación. Treballs d'Arqueologia, 12, 111-126.

Mitchell, L. (2018). Ludopolitics: Videogames Against Control. Alresford: John Hunt Publishing.

Muriel, D., \& Crawford, G. (2018). Video games as culture: considering the role and importance of video games in contemporary society. Oxford: Routledge.

Paredes-Otero, G. (2018). Análisis de la imagen de la mujer transmitida en las actuales carátulas de videojuegos. Ámbitos. Revista Internacional de Comunicación, 40, 190-199. https://doi.org/10.12795/Ambitos.2018.i40.23

Pérez Latorre, Ó. (2011). Géneros de juegos y videojuegos: una aproximación desde diversas perspectivas teóricas. Comunicació: Revista de Recerca i d'anàlisi, 28(1), 127-146. https://doi.org/10.2436/20.3008.01.81 
Ramalho, J. E., Simão, F., \& Paulo, A. B. D. (2014). Aprendizagem por meio de jogos digitais: um estudo de caso do jogo animal crossing. Ensaios Pedagógicos-Revista Eletrônica Do Curso de Pedagogia Das Faculdades OPET.

Ramos-Serrano, M., \& Herrero-Diz, P. (2016). Unboxing and brands: Youtubers phenomenon through the case study of evantubehd. Prisma Social, 1, 91-120. Retrieved from https://revistaprismasocial.es/article/view/1315

Ramos-Serrano, M., Lozano-Delmar, J., \& Hernández-Santaolalla, V. (2012). Fanadvertising y series de televisión. Comunicación: Revista Internacional de Comunicación Audiovisual, Publicidad y Estudios Culturales, 10, 1211-1223.

Rojo, T., \& Dudu, S. (2017). Los videojuegos en la implementación de políticas de mitigación del cambio climático. Ambitos: Revista Internacional de Comunicación, 37. Retrieved from https://revistascientificas.us.es/index.php/Ambitos/article/view/9104

Stanfill, M. (2019). Exploiting fandom. How the media industry seek to manipulate fans. lowa: University of lowa Press.

\section{Artwork used as study sample}

16mmDJ (February, 3, 2014). Animal Crossing: Gender Glitch. [Video]. Retrieved from https://www.youtube.com/watch?v=F-yZe2903i0

Aliensliveinme (March, 3, 2014). Animal crossing new leaf, cross dressing makes you run like a girl. [Video]. Retrieved from https://www.youtube.com/watch?v=0CX94k117ao

BanetteDoddles (June, 27, 2018). Comissions! [Re Post]. [Blog post]. Retrieved from https://aminoapps.com/c/animal-crossing/page/blog/commissions-re-

post/eZVo_3Ec3u2bRBLMqBJ23870GELwbjpon

Compy Cubert (July, 10, 2018). Image. Computer Garden. [Blog post]. 2018. http://cubert.tumblr.com/post/175738819056

Cosmic kevvv (June, 25, 2013). Animal Crossing New Leaf:Crossgender Haircuts. [Video]. Retrieved from https://www.youtube.com/watch?v=LR4mlgBZet4

Finngamer (November, 19, 2015). Amiibo review: Animal Crossing, wave 1. [Video]. Retrieved from https://www.youtube.com/watch?v=gECldXAErlA\&t=216s

Heather (June, 9, 2017). Acnl Villager Memes. [Blog post]. Retrieved from https://www.x2u.club/acnl-villager-memes.html

Hotdiggedydemon (January, 22, 2016). Isabelle Ruins Everything (Animal Crossing Parody). [Video]. Retrieved from https://www.youtube.com/watch?v=VeWC9V2qH-8

Isabellefacts 1 (February, 16, 2019). "isabelle fact 1: isabelle is a cannon lgbtq + character." [Tweet]. Retrieved from https://twitter.com/isabellefacts1/status/1096751934097088512 
Joetheblogger (2011). Occupy Animal Crossing. [Blog post]. Retrieved from https://stfuconservatives.tumblr.com/post/11684091691

Kazenoabs0 (May, 7, 2015). Picture memes SLHqSL3u2. [Blog post]. Retrieved from https://ifunny.co/picture/SLHqSL3u2?gallery=tag\&query=isabelle

Los Juegos de SaG (October, 13, 2016). ¡MALDITA ALCALDESA NEOLIBERAL!: Animal Crossing New Leaf para 3DS \#JugamosaDobles \#LaVenganzaDeLeven. [Video] https://www.youtube.com/watch?v=bO6z4xXJ2Kw\&t=191s

Mayor Mori (October, 21, 2016). Nintendo Switch: Animal Crossing Trailer (fan made). [Video]. Retrieved from https://www.youtube.com/watch?v=II1qZ_JVI2w

MissPolycysticOvary (2014). Oh,Mayor!. [Blog post]. Retrieved from https://www.deviantart.com/misspolycysticovary/art/Oh-Mayor-464985098

Nisego Channel (September, 17, 2015). Animal Crossing - Isabelle Fan Art. [Video]. Retrieved from https://www.youtube.com/watch?v=PS4gq1-oPtc

RandomMan (2014). “Image \#558,726." [Image]. Retrieved from https://knowyourmeme.com/photos/558726-animal-crossing

Starchie (2018). Super Smash Brothers Ultimate - Isabelle and Villager reunited. [Image] Retrieved from https://knowyourmeme.com/photos/1410214-super-smash-brothersultimate

Teamlpsandacnl (2019). Isabelle Alt. [Image]. Retrieved from https://www.memecenter.com/fun/7266234/isabelle-alt/ 